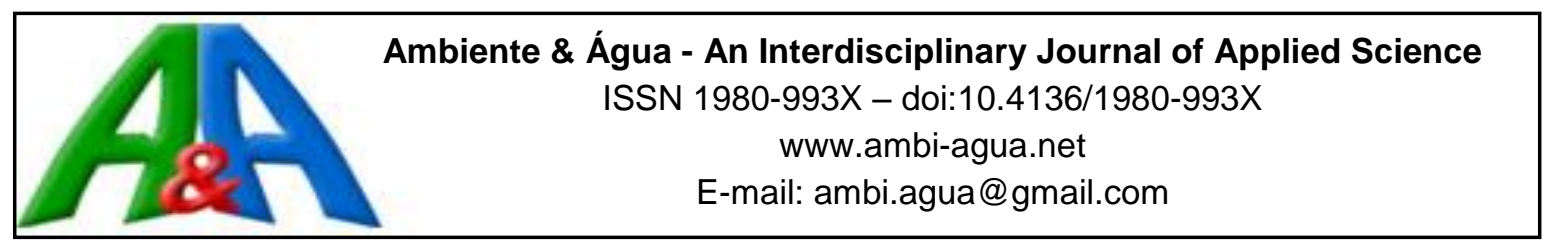

\title{
Space-time variability of evapotranspiration and precipitation in the State of Paraná, Brazil
}

\author{
doi:10.4136/ambi-agua.2057 \\ Received: 02 Dec. 2016; Accepted: 13 Jun. 2017 \\ Lucas da Costa Santos ${ }^{1 *}$; Jefferson Vieira José²; \\ Daniel Soares Alves ${ }^{3}$; Pablo Ricardo Nitsche ${ }^{4}$; \\ Elton Fialho dos Reis ${ }^{1}$; Fabiani Denise Bender ${ }^{2}$ \\ ${ }^{1}$ Universidade Estadual de Goiás (UEG), Anápolis, GO, Brasil \\ Departamento de Engenharia Agrícola \\ ${ }^{2}$ Escola Superior de Agricultura "Luiz de Queiroz" (ESALQ/USP), Piracicaba, SP, Brasil \\ Departamento de Engenharia de Biosistemas \\ ${ }^{3}$ Universidade do Estado de Mato Grosso (UNEMAT), Tangará da Serra, MT, Brasil \\ Departamento de Engenharia Agrícola \\ ${ }^{4}$ Instituto Agronômico do Paraná (IAPAR), Londrina, PR, Brasil \\ Área de Agrometeorologia \\ *Corresponding author: e-mail: lucas.cs21@gmail.com,jfvieira@usp.br, \\ danielsoares@unemat.br,pablo@iapar.br, fialhoreis@ueg.br, \\ fabianidenise@gmail.com
}

\begin{abstract}
Long-term changes in important weather variables such as evapotranspiration (ET) and precipitation are expected as a response to climate change. These changes may require adjustments to current strategies of planning and management of water resources. The objective of this work was to conduct a spatiotemporal characterization of evapotranspiration in the State of Paraná, Brazil, including in this approach a temporal trend analysis. A similar analysis was also conducted for precipitation. Thus, the historical data (1980-2010) from 33 weather stations were analyzed. The spatial distribution of the data was carried out by geostatistical techniques (ordinary kriging) and the trend analysis by the tests Mann-Kendall and Sen. According to the results, evapotranspiration increases from the coast to the interior of the state, with the highest values in the northeast and northwest regions, reaching levels of about $1200 \mathrm{~mm} \mathrm{yr}^{-1}$. The temporal variability of the ET presented a significant upward trend in $12 \%$ of the locations, with increases from 2.5 to $7.0 \mathrm{~mm} \mathrm{yr}^{-1}$. Precipitation was higher in the coastal and south-central regions and the lowest amounts were identified in the northeast and northwest regions. The precipitation trend analysis indicated a significant downward trend in precipitation volume of five locations. The evapotranspiration and precipitation showed, in general, no statistically significant trends in most of the stations analyzed; however, the upward trends for ET and downward trends for precipitation indicate local changes in the State of Paraná.
\end{abstract}

Keywords: climate change, evapotranspiration demand, regionalization. 


\section{Variabilidade espaço-temporal da evapotranspiração e precipitação para o Estado do Paraná}

\section{RESUMO}

Como reflexos das alterações advindas das mudanças climáticas, espera-se modificações de longo prazo em importantes variáveis meteorológicas, tais como evapotranspiração (ET) e precipitação, as quais podem demandar ajustes nas atuais estratégias de planejamento e gestão dos recursos hídricos. Neste estudo, objetivou-se realizar a caracterização espaço-temporal da variável evapotranspiração para o estado do Paraná, associando a essa abordagem uma análise de tendência temporal. Complementarmente, foi realizada análise similar para a precipitação. Para este propósito analisou-se uma série histórica de dados que compreende ao período de 1980-2010, obtidos em 33 estações meteorológicas. A espacialização dos dados foi feita a partir de técnicas geoestatísticas (krigagem ordinária) e as análises de tendências com os testes de Mann-Kendall e Sen. Os resultados indicaram que a evapotranspiração aumenta do litoral para o interior do estado, com os maiores valores ocorrendo nas regiões nordeste e noroeste, atingindo patamares da ordem de $1200 \mathrm{~mm}^{\text {ano }}{ }^{-1}$. Quanto a variabilidade temporal da ET, notou-se tendência significativa de aumento em 12\% das localidades estudadas, com a magnitude destas tendências variando entre 2,5 a 7,0 $\mathrm{mm}$ ano ${ }^{-1}$. A precipitação foi maior nas regiões litorâneas e centro-sul e as menores alturas foram identificadas nas regiões nordeste e noroeste. A análise de tendência para a precipitação apontou redução significativa em cinco localidades. De modo geral, as variáveis evapotranspiração e precipitação não apresentaram tendências estatisticamente significativas na maior parte das estações. No entanto, as tendências de aumento e redução generalizadas para a ET e precipitação, respectivamente, sugerem alterações de caráter localizado no território paranaense.

Palavras-chave: demanda evapotranspirométrica, mudança climática, regionalização.

\section{INTRODUCTION}

Better water use planning and management is essential in various economic activities, and especially for agricultural production. It became necessary due to the lower availability of water resources, in both quantity and quality, and to increasing demand.

Together with precipitation, evapotranspiration (ET) is a basic component of the water cycle. The process involves the transference of water to the atmosphere through transpiration and evaporation in a soil-plant system, and is an important parameter for climatological and hydrological studies, as well as for irrigation planning and management (Sentelhas et al., 2010).

Due to the significant role that ET plays in local and regional climates, estimations must be made with accuracy, given its importance in the evaluations of soil-water input, crop yield forecasting, and especially, land-use planning (Li et al., 2009).

ET values are, in general, estimated through models using data from standard meteorological network stations. Penman-Monteith is the most accepted ET estimation method, due to its good performance in temperate and tropical climate environments, and is recommended by the Food Agriculture Organization of the United Nations (FAO) in its Bulletin 56 (Allen et al., 1998).

ET has great spatial and temporal variations, along with the biological and meteorological factors that determine it. The vegetation spatial and temporal heterogeneity and soil coverage level, as well as the differences in available energy and water, affect the ET rate (Khalil et al., 2015).

According to Mauser and Schadlich (1998), in addition to the natural spatial variability in ET, changes in the vegetation cover due human interference are occurring locally, through the 
introduction of new species or modifications carried out by agriculture/or silviculture, and also regionally, through deforestation, increasing irrigation area and also desertification processes, especially in areas of arid and semi-arid climates.

Paraná is one of the major producing states of agricultural commodities in Brazil, especially grains, standing as the largest producers of beans and wheat, and the second largest producer of corn and soybean crops. Paraná is also the fifth largest producer of coffee and sugarcane (CONAB, 2016). Given the importance of this state to Brazilian agricultural production, it is believed that the use of spatialized climatological information can be a powerful tool for planning, decision-making and development of policies for agriculture activity.

As far as we know, there are no studies of spatialized evapotranspiration for the state of Paraná; moreover, they have local approaches (Souza et al., 2014; Jerszurki et al., 2015) with limited covered areas. On the other hand, studies on spatial and temporal variability of precipitation are more frequent (Silva and Guetter, 2003; Minuzzi and Caramori, 2011; Silva et al., 2015), thus, an analysis at the state level, encompassing a consistent historical database of ET can help to identify possible changes in the ET, improving activities that are directly affected by it, such as the irrigated agriculture. This understanding was also supported by Xu et al. (2006), who stated that ET data when regionalized become valuable information in the planning of the use of water resources, considering the importance of this variable as the driving force of the hydrological cycle. In the same vein, Hess et al. (2016) warn that managers and others interested in water use should carefully consider the implications of ETo's spatial variability, always associating the demand for this resource with its forecast supply.

In this context, the objective of this work was to perform a spatiotemporal characterization of ET in the State of Paraná, Brazil, including in this approach a temporal trend analysis for its occurrence and quantification. A similar analysis was also conducted for the precipitation to identify potential relationships between these two variables.

\section{MATERIAL AND METHODS}

\subsection{Study area}

Paraná is located between the parallels $22^{\circ}$ and $27^{\circ} \mathrm{S}$, presenting various types of climate, soil and vegetative cover, and different geological formation and geomorphological conformation. According to the climate classification system of Koppen, the state has, predominantly, two climate types, namely Cfa (mesothermal subtropical with hot summers and trend of rainfall concentration in the summer, however, with no dry season) and $\mathrm{Cfb}$ (temperate, mesothermal, with cool summers and with no dry season); the first occurs in the east-central region of the state and the second one occurs in the northern and western regions (Pedron and Klosowski, 2008).

\subsection{Meteorological data}

The dataset used in this study is from 33 conventional weather stations of the Agronomic Institute of Paraná (IAPAR) spread across the state (Figure 1 and Table 1). These data represented the period from January 01, 1980 to December 31, 2010, which is a relatively long series of data, thus, there were registration failures of up to $10 \%$ of missing data in all studied stations. These failures were fixed with the database developed by Xavier et al. (2015), which interpolates the daily data from various sources and is available in high-resolution spacing $\left(0.25^{\circ} \times 0.25^{\circ}\right)$, including all weather variables here evaluated.

The meteorological parameters used were maximum, minimum and average temperature and average relative humidity, solar radiation, wind speed and precipitation. The estimation of 
the reference evapotranspiration $\left(\mathrm{ET}_{0}\right)$ was carried out through the Penman-Monteith method, as shown in Equation 1.

$$
\mathrm{ET}_{0}=\frac{0.408 \Delta\left(\mathrm{R}_{\mathrm{n}}-\mathrm{G}\right)+\gamma[900 /(\mathrm{T}+273)] \mathrm{U}_{2}\left(\mathrm{e}_{\mathrm{a}}-\mathrm{e}_{\mathrm{s}}\right)}{\Delta+\gamma\left(1+0.34 \mathrm{U}_{2}\right)}
$$

where:

$\mathrm{Rn}$ is the net radiation $\left(\mathrm{MJ} \mathrm{m}^{-2} \mathrm{day}^{-1}\right)$;

$\mathrm{T}$ is the mean temperature of the day, measured at two meters high $\left({ }^{\circ} \mathrm{C}\right)$;

$\mathrm{U}_{2}$ is the average wind speed at two meters high $\left(\mathrm{m} \mathrm{s}^{-1}\right)$;

$\Delta$ is the slope of the saturated vapor curve $\left(\mathrm{kPa}^{\circ} \mathrm{C}^{-1}\right)$;

$\mathrm{G}$ is the heat flow of the soil $\left(\mathrm{MJ} \mathrm{m}^{-2} \mathrm{day}^{-1}\right)$;

$\gamma$ is the psychrometric constant $\left(\mathrm{kPa}^{\circ} \mathrm{C}^{-1}\right)$;

$\mathrm{e}_{\mathrm{a}}$ is the current vapor pressure $(\mathrm{kPa})$; and

$\mathrm{e}_{\mathrm{s}}$ is the saturation vapor pressure $(\mathrm{kPa})$.

The net radiation was determined by Equation 2, proposed by Allen et al. (1998).

$$
\mathrm{R}_{\mathrm{n}}=\mathrm{Q}_{\mathrm{g}}(1-\alpha)-\left[4,903 \cdot 10^{-9}\left[\frac{\mathrm{T}_{\max }^{4}+\mathrm{T}_{\min }^{4}}{2}\right]\left(0.34-0.14 \sqrt{\mathrm{e}_{\mathrm{a}}}\right)\left(1.35 \frac{\mathrm{Q}_{\mathrm{g}}}{\mathrm{Q}_{\mathrm{gcs}}}-0.35\right)\right]
$$

where:

$\alpha$ is the albedo, which was considered as 0.25 ;

$\mathrm{T}_{\max }$ and $\mathrm{T}_{\min }$ are the maximum and minimum daily temperatures;

$\mathrm{Q}_{\mathrm{g}}$ is the global solar radiation $\left(\mathrm{MJ} \mathrm{m}^{-2} \mathrm{day}^{-1}\right)$, and

$\mathrm{Q}_{\mathrm{cs}}$ is the hypothetical solar radiation on a clear-sky day $\left(\mathrm{MJ} \mathrm{m}^{-2} \mathrm{day}^{-1}\right)$, which was determined by Equation 3 .

$$
\mathrm{Q}_{\mathrm{gcs}}=\left(0.75+2 \cdot 10^{-5} \mathrm{z}\right) \mathrm{Q}_{\mathrm{o}}
$$

where:

$\mathrm{Z}$ is the local altitude (m), and

$\mathrm{Q}_{\mathrm{o}}$ is the extraterrestrial radiation $\left(\mathrm{MJ} \mathrm{m}^{-2} \mathrm{day}^{-1}\right)$, based on the latitude of the area and time of the year, based on the expressions described by Allen et al. (1998).

The $\mathrm{ET}_{0}$ values accumulated were divided into periods of one year $\left(\mathrm{ET}_{0 \mathrm{AC}}\right)$. These values were used to characterize the spatial and temporal variability of the evapotranspiration demand. The precipitation was evaluated through a similar methodology to the $\mathrm{ET}_{0 \mathrm{AC}}$. 


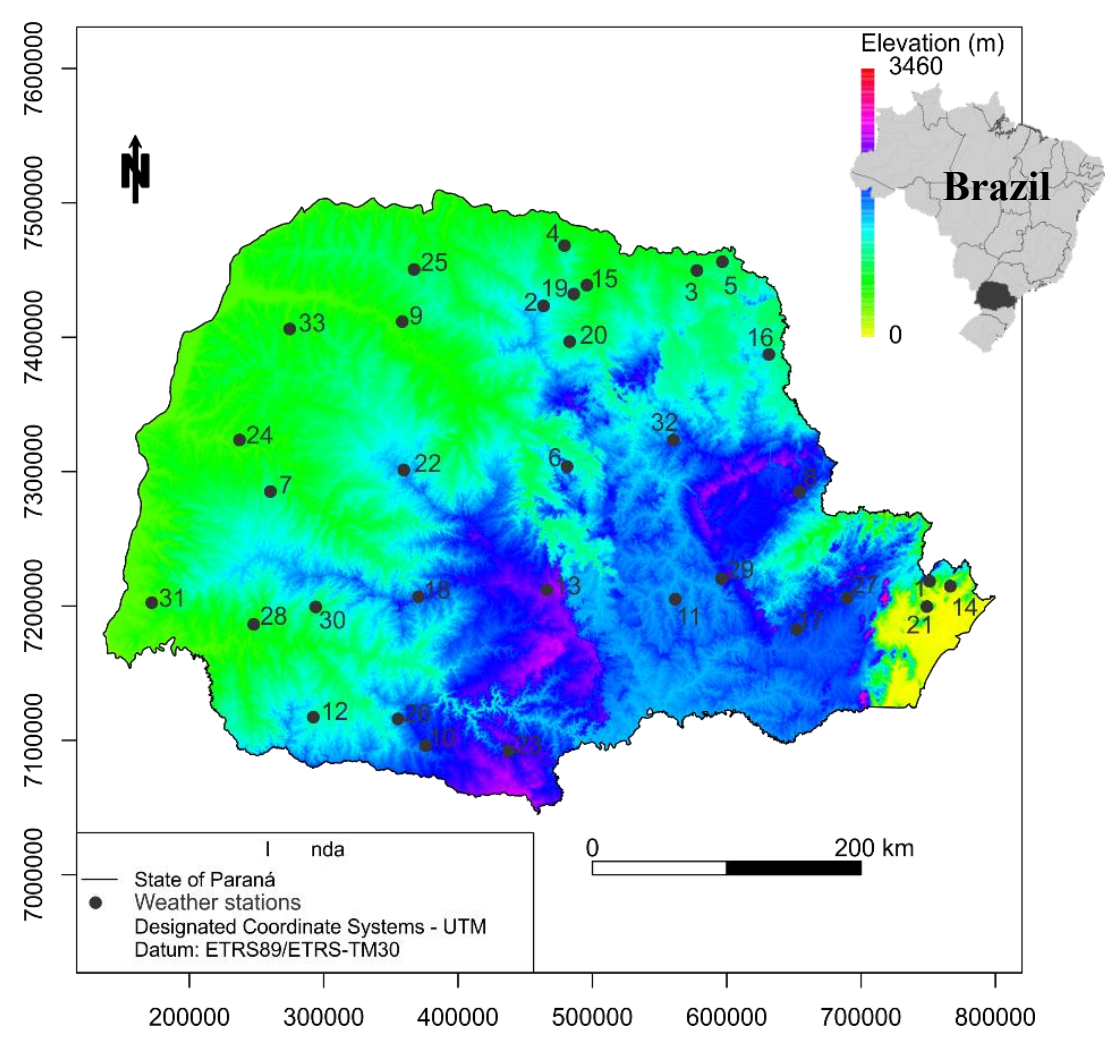

Figure 1. Altitude, localization and distribution of weather stations studied in the state of Paraná, Brazil.

Table 1. Localization and altitude of the weather stations studied the state of Parana, Brazil.

\begin{tabular}{lccclccc}
\hline Weather Station & Lat. & Long. & Alt. $(\mathrm{m})$ & Weather Station & Lat. & Long. & Alt. $(\mathrm{m})$ \\
\hline 1-Antonina & -25.13 & -48.48 & 60 & 18-Laranjeiras do Sul & $-25,25$ & -52.25 & 880 \\
2-Apucarana & -23.30 & -51.32 & 746 & 19-Londrina & -23.22 & -51.10 & 585 \\
3-Bandeirantes & -23.06 & -50.21 & 440 & 20-Mauá da Serra & -23.54 & -51.13 & 1020 \\
4-Bela Vista do Paraíso & -22.57 & -51.12 & 600 & 21-Morretes & -25.30 & -48.49 & 59 \\
5-Cambará & -23.00 & -50.02 & 450 & 22-Nova Cantu & -24.40 & -52.34 & 540 \\
6-Cândido de Abreu & -24.38 & -51.15 & 645 & 23-Palmas & -26.29 & -51.59 & 1100 \\
7-Cascavel & -24.53 & -53.33 & 660 & 24-Palotina & -24.18 & -53.55 & 310 \\
8-Cerro Azul & -24.49 & -49.15 & 360 & 25-Paranavaí & -23.05 & -52.26 & 480 \\
9-Cianorte & -23.40 & -52.35 & 530 & 26-Pato Branco & -26.07 & -52.41 & 700 \\
10-Clevelândia & -26.25 & -52.21 & 930 & 27-Pinhais & -25.25 & -49.08 & 930 \\
11-Fernandes Pinheiro & -25.27 & -50.35 & 893 & 28-Planalto & -25.42 & -53.47 & 400 \\
12-Francisco Beltrão & -26.05 & -53.04 & 650 & 29-Ponta Grossa & -25.13 & -50.01 & 880 \\
13-Guarapuava & -25.21 & -51.30 & 1058 & 30-Quedas do Iguaçu & -25.31 & -53.01 & 513 \\
14-Guaraqueçaba & -25.16 & -48.32 & 40 & 31-São Miguel Iguaçu & -25.26 & -54.22 & 260 \\
15-Ibiporã & -23.16 & -51.01 & 484 & 32-Telêmaco Borba & -24.20 & -50.37 & 768 \\
16-Joaquim Távora & -23.30 & -49.57 & 512 & 33-Umuarama & -23.44 & -53.17 & 480 \\
17-Lapa & -25.47 & -49.46 & 910 & & & & \\
\hline
\end{tabular}

Lat. - Latitude; Long. - Longitude; Alt - Altitude. 


\subsection{Trend tests}

The trend analysis aimed to identify the maintenance, increase or reduction of the $\mathrm{ET}_{0 \mathrm{AC}}$ values in the time series, using the non-parametric Mann-Kendall (MK) test.

The MK test was analyzed from the coefficients $\tau$ (tau) and $s$ of Mann-Kendall, both used to identify correlations between the variables. The coefficient $\tau$ is defined by the relationship between the score of a real classification of correlation to the maximum possible score. To obtain the score for a data series, the data set should be sorted in ascending order, according to the order of occurrence (chronological), and then the following equation is applied (Equation 4):

$$
S=\sum_{j=1}^{j=n-1} \sum_{i=j+1}^{i=n} \operatorname{sgn}\left(x_{i}-x_{j}\right)
$$

where:

$\mathrm{S}$ is the classification score (also called Mann-Kendall sum);

$\mathrm{x}$ is the value of the data;

$\mathrm{i}$ and $\mathrm{j}$ are the estimated values of the data sequence;

$\mathrm{n}$ is the number of data of the series and

sgn is a function that establishes values of $-1,0$ and 1 , when $(x-x j)$ is negative, zero or positive, respectively.

According to Equation 5, the maximum value of $\mathrm{S}$ is:

$$
\mathrm{S}_{\max }=\frac{1}{2} \mathrm{n}(\mathrm{n}-1)
$$

Thus, Kendall tau $(\tau)$ is calculated as (Equation 6).

$$
\tau=\frac{\mathrm{S}}{\mathrm{S}_{\max }}
$$

A positive value of s or $\tau$ indicates an upward trend, and a negative value indicates a downward trend. However, the probability associated with s or $\tau$ and sample size (n) must be calculated to quantify the statistical significance of the trend. Kendall and Gibbons (1990) introduced a normal approach test that can be applied to datasets of more than ten values, with variance $\mathrm{s}\left(\sigma^{2}\right)$ (Equations 7 and 8$)$.

$$
\begin{aligned}
& \sigma^{2}=\frac{1}{18} \mathrm{n}(\mathrm{n}-1)(2 \mathrm{n}+5)-\mathrm{CF}_{\mathrm{R}} \\
& \mathrm{CF}_{\mathrm{R}}=\frac{1}{18} \sum_{\mathrm{k}=1}^{\mathrm{g}} \mathrm{m}_{\mathrm{k}}\left(\mathrm{m}_{\mathrm{k}}-1\right)\left(2 \mathrm{~m}_{\mathrm{k}}+5\right)
\end{aligned}
$$

where:

$\mathrm{CF}_{\mathrm{R}}$ is a correction factor for repetition, to correct the effect of data groups (when some of the data values appear more than once in the dataset, this set of values is called linked group);

$\mathrm{g}$ is the number of linked groups;

$\mathrm{k}$ is a counter; $\mathrm{m}$ is the number of data values in each linked group. 
Then, the normal distribution parameter (called statistics of Mann-Kendall, Z) was calculated by Equation 9 .

$$
Z=\left\{\begin{array}{c}
\frac{1}{\sigma}(s-1) \text { se } S>0 \\
0 \text { se } S=0 \\
\frac{1}{\sigma}(s+1) \text { se } S<0
\end{array}\right.
$$

The last step was to find the minimum level of probability in which the $\mathrm{Z}$ parameter is significant, using statistical tables (two-tailed) or according to the equation (Equation 10) described by Abramowitz and Stegun (1972).

$$
\alpha_{\min }=\left(\mathrm{b}_{0} \mathrm{e}^{-0.5 \mathrm{z}^{2}}\right) \sum_{\mathrm{q}=1}^{\mathrm{q}=5} \mathrm{~b}_{\mathrm{q}} \cdot\left(1+\mathrm{b}_{6} \operatorname{ABS}(\mathrm{Z})\right)^{-\mathrm{q}}
$$

where:

$\alpha_{\min }$ is the minimum level of significance;

$\mathrm{q}$ is the number of values;

$b_{\mathrm{x}}$ are the constants $\left(b_{0}=0.3989\right.$,

$\mathrm{b}_{1}=0.3194$,

$\mathrm{b}_{2}=-0.3566$,

$\mathrm{b}_{3}=1.7814$,

$\mathrm{b}_{4}=-1.8213$,

$\mathrm{b}_{5}=1.3303$,

$\left.\mathrm{b}_{6}=0.2316\right)$; and

$\mathrm{ABS}(\mathrm{Z})$ is a function for the absolute value of $\mathrm{Z}$.

The Kendall's tau $(\tau)$ is significant at significance level of $5 \%(\mathrm{p}<0.05)$ when $\alpha_{\min }$ is lower than a specified value alpha.

The slope of the trend of the data series was calculated according to the method described by Sen (1968). The Sen test must be carried out observing various rules and conditions, such as time series equally spaced, i.e., equal intervals between the data points. However, missing data can be considered in this method. The data must be sorted in ascending order according to the time and then applying (chronological) Equation 11 to calculate the Sen slope estimator (Q) as the median of members of the array of Sen.

$$
Q=\operatorname{Median}\left\{\left[\left[\frac{x_{1-x_{j}}}{1-j}\right]^{j=n-1} \begin{array}{c}
i=n \\
j=1
\end{array}\right] \begin{array}{c}
i=j+1
\end{array}\right\}
$$

The Q signal denotes the trend direction, while its value denotes how steep the trend is. Equation 7 was used to determine if the average slope was statistically different from zero, obtaining the confidence interval of $Q$ to a certain level of probability. The area $(Z)$ under the two-tailed normal distribution curve was calculated by $\left(1-\frac{\alpha}{2}\right)$, in which $\alpha=1$ - confidence 
level, i.e. for a $95 \%$ confidence level, $\mathrm{Z}$ must be evaluated at 0.975 , therefore, $\mathrm{Z}=1.96$. After that, the $\mathrm{C}_{\alpha}$ parameter was calculated from Equation 12.

$$
\mathrm{C}_{\alpha}=\mathrm{Z}_{1-\alpha / 2} \sqrt{\sigma^{2}}
$$

\subsection{Geostatistics}

With the annual mean values of the variables air temperature, vapor pressure deficit, precipitation and accumulated $\mathrm{ET}_{0}$, a geostatistical analysis of these variables was carried out, aiming to regionalize them to the study area. The variables were analyzed under the geostatistical models approach (Diggle and Ribeiro Junior, 2007). In this way, the parameters of the model were adjusted by the maximum likelihood method. Different trend models were tested, defined by linear and quadratic relations between the covariates $\mathrm{X}, \mathrm{Y}$ and elevation at the locations of the meteorological stations. Therefore, the best spatial trend withdrawal model was chosen, and five models of candidate covariance functions were tested: exponential; Gaussian; spherical; circular and matern, with a softness parameter of 1.5 and 2.5. After choosing the model and estimating its parameters, ordinary kriging was used to interpolate the studied variables. The choice of the best model was based on the Akaike Information Criterion (AIC), so the tested distributions that presented the best performance (lower AIC value) were used. The Gaussian model was used to estimate the mean annual temperature. For the variables of vapor pressure, precipitation and $\mathrm{ET}_{0}$, the exponential model was used.

\subsection{Data analysis}

The precipitation data, estimates of the $\mathrm{ET}_{0}$ series, goodness of fit test and other statistical calculations were performed using the software XLSTAT-2011.3.02. The software R Statistical 3.1.2 ${ }^{\circledR}$ (R CORE TEAM, 2016) was used for the geostatistical (geoR, MASS, rgdal and raster packages) and graphical (RcolorBrewer, maptools and SDMTools packages) analysis.

\section{RESULTS AND DISCUSSION}

\subsection{Regionalization of the $\mathbf{E T}_{0}$ in the State of Paraná}

The spatial distribution of the annual reference evapotranspiration (average of 31 years) (Figure 2A) denotes the combined effect of all the climatological factors that determine this variable.

The average values of $\mathrm{ET}_{0 \mathrm{AC}}$ varied from 578.6 to $1231.9 \mathrm{~mm} \mathrm{yr}^{-1}$, denoting a high spatial variability. The lowest ET $_{0 \mathrm{AC}}$ was found in Guarapuava, which is located in the south-central region of the state, at an altitude over 1000 meters, probably due to this region's milder temperatures. The group with the lowest ET $_{0 \mathrm{AC}}$ also includes Morretes, Antonina and Pinhais. The lower $\mathrm{ET}_{0 \mathrm{AC}}$ values were related to high altitudes or proximity to the coast of the regions, where the maritime is most pronounced (Figure 1 and Table 1).

The region with the highest evapotranspirometric demand is located in the northern portion of the state (Bandeirantes, Paranavaí, Umuarama and Ibiporã), with $\mathrm{ET}_{0 \mathrm{AC}}$ values of about $1200 \mathrm{~mm} \mathrm{yr}^{-1}$. The counties that integrate this region have highest air temperatures and vapor pressure deficit and smaller rainfall accumulated (Figures 2B, 2C and 2D); these conditions justify the magnitude of evapotranspiration in these regions.

According to $\mathrm{Xu}$ et al. (2006), this information when regionalized is valuable in planning the use of water resources, considering the importance of evapotranspiration as the driving force of the hydrological cycle. Similarly, Hess et al. (2016) warn that managers and others interested in water use should carefully consider the implications of ETo spatial variability, always associating the demand for this resource with its forecast supply. 

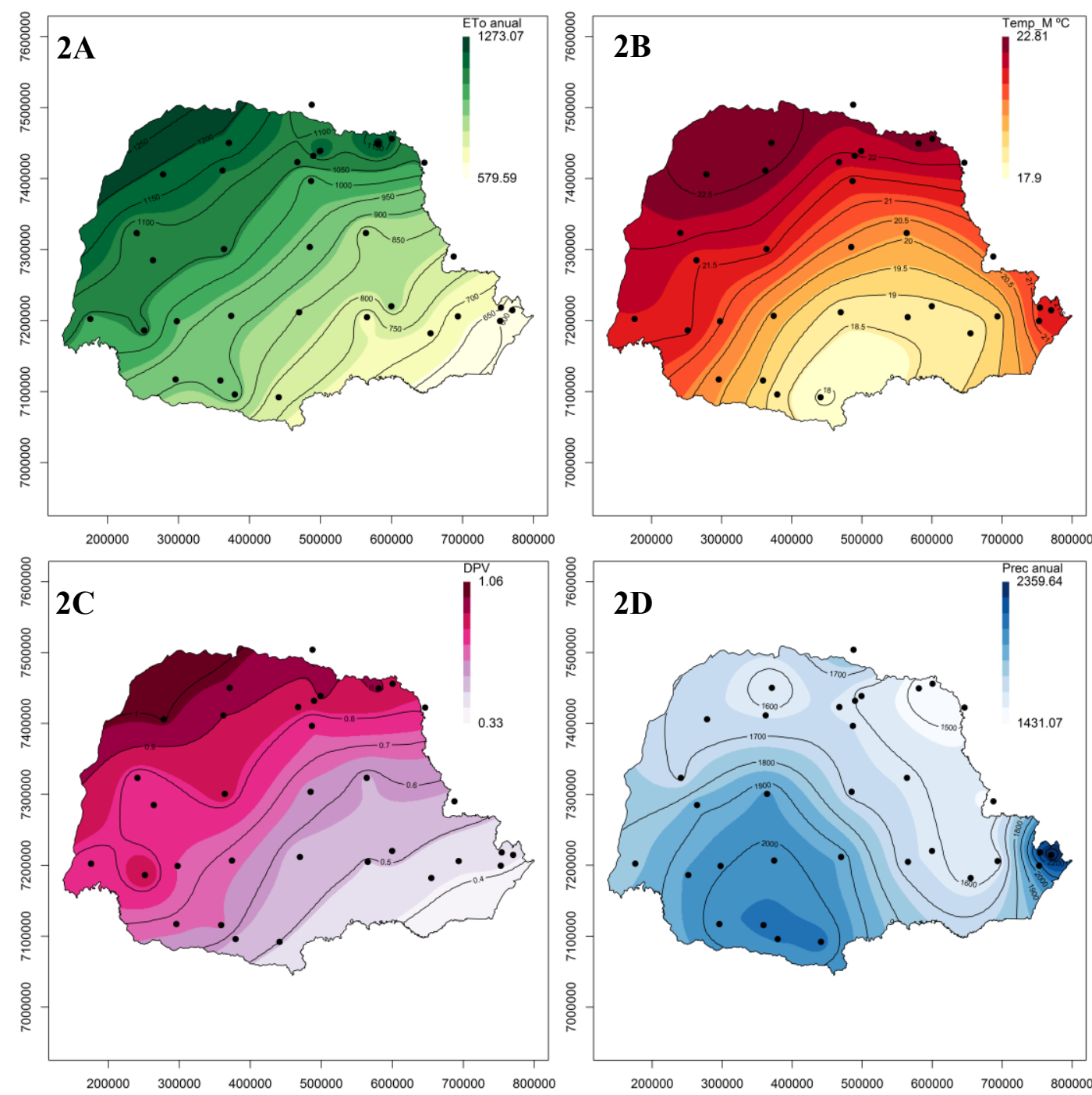

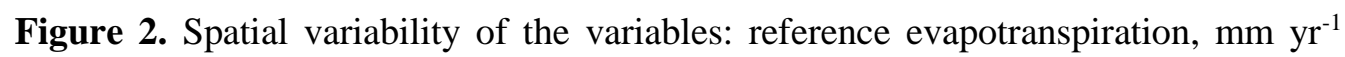
(2A); average annual temperature, ${ }^{\circ} \mathrm{C}(2 \mathrm{~B})$; average annual vapor pressure deficit, $\mathrm{kPa}$ (2C) and accumulated annual rainfall, $\mathrm{mm}(2 \mathrm{D})$ in the state of Paraná (annual average obtained from the period $1980-2010$ ).

\subsection{ETo trend analysis in Paraná}

The annual and daily mean values of $\mathrm{ET}_{0}$ of each location and the statistical results of the Mann-Kendall and Sen tests for temporal trend analysis of this variable (Table 2) showed that only 4 of the 33 locations showed significant upward trend $(\mathrm{p}<0.05)$ of $\mathrm{ET}_{0}$ values. These locations were in the eastern (Antonina, Pinhais), south (Cascavel) and north-central (Mauá da Serra) regions of the state. The $\mathrm{ET}_{0 \mathrm{AC}}$ increase rates (Sen test) ranged from 2.53 (Pinhais) to $7.02 \mathrm{~mm} \mathrm{yr}^{-1}$ (Mauá da Serra).

The factors affecting the $\mathrm{ET}_{0}$ upward trend for these locations are not clear, mainly due to the different characteristics of these regions, such as altitude, industrialization level, continentality and maritime. However, Tabari and Talaee (2001a) studied air temperature trends in western Iran and reported increases in the minimum temperature values as the probable cause of increase in evapotranspiration. In fact, significant increases of minimum temperature were found in Cascavel ( $\mathrm{p}$-value $=0.03$ ), Mauá da Serra ( $\mathrm{p}$-value $=0.01$ ) and Pinhais $(\mathrm{p}$-value $=0.01)$

Overall, $70 \%$ of the locations studied presented an $\mathrm{ET}_{0}$ upward trend (positive). This result indicates that the climate variability is affecting the state of Paraná, increasing its 
evapotranspiration demand with time; however, the analysis of larger historical data is necessary to statistically confirm this trend.

Cambará, Francisco Beltrão, Guaraqueçaba, Ibiporã, Lapa, Morretes, Nova Cantu, Paranavaí, Ponta Grossa and Umuarama presented an $\mathrm{ET}_{0}$ downward trend, although none of them had statistically significant $(\mathrm{p}<0.05)$ tau coefficient $(\tau)$. The $\mathrm{ET}_{0}$ analyzes by the Sen coefficient presented weaker downward trends compared with upward trends, with reduction rates lower than $2.0 \mathrm{~mm} \mathrm{yr}^{-1}$.

$\mathrm{ET}_{0}$ downward trends found in China (Thomas, 2000), Iran (Tabari, et al., 2011b) and India (Jhajharia et al., 2012) had similar results to those in the present work. According to these authors, the $\mathrm{ET}_{0}$ reductions were due to significant decreases in wind speed and net radiation, the latter probably due to monsoons, which are common in those regions. Brazil has virtually no monsoons, thus, the reduction of the $\mathrm{ET}_{0}$ can be attributed to the reduction in wind speed, which, according to Fan and Thomas (2013), is due to changes in the soil surface, thus related to changes of soil coverage and land use and purpose.

Ten locations presented downward $\mathrm{ET}_{0}$ trends, but only three had no significant $(\mathrm{p}<0.05)$ downward trends for wind speed, Ponta Grossa $(\mathrm{p}=0.5)$, Francisco Beltrão $(\mathrm{p}=0.13)$ and Lapa ( $\mathrm{p}=0.07)$. These results confirm those found by McVicar et al. (2012), who analyzed 148 studies on wind dynamic around the world and reported that reductions in wind speed have reduced the atmospheric evaporative demand.

The different evapotranspiration demand trends of the State of Paraná were compared and presented positive, negative and neutral variation rates of $\mathrm{ET}_{0 \mathrm{AC}}$, respectively in Mauá da Serra (7.0 mm yr $\left.{ }^{-1}\right)$, Paranavaí (-2.0 $\left.\mathrm{mm} \mathrm{yr}^{-1}\right)$ and Cerro Azul $\left(0.1 \mathrm{~mm} \mathrm{yr}^{-1}\right)$ (Figure 3). Thus, according to these results, e.g., variations of trends, the $\mathrm{ET}_{0}$ must be regionalized as a routine practice in researches related to water demand of terrestrial ecosystems, especially for agriculture due to the importance of water to crop growth.

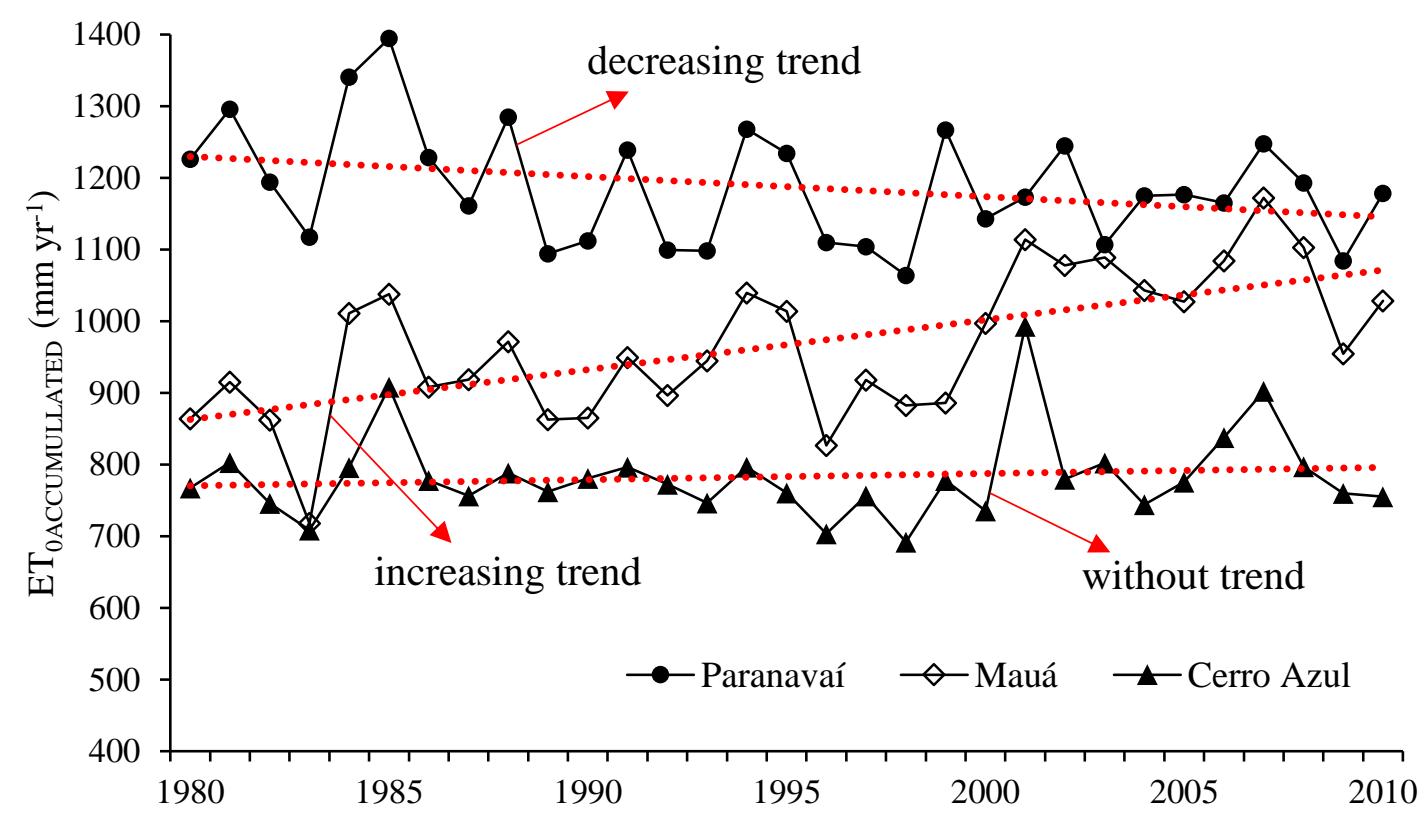

Figure 3. Trend for evapotranspiration accumulated reference in the locations of Mauá da Serra, Paranavaí and Cerro Azul for the period 1980-2010 in the state of Paraná. 
Table 2. Average annual cumulative evapotranspiration $\left(\mathrm{ET}_{0 \mathrm{AC}}\right)$, average daily evapotranspiration (ET $\left.0 \mathrm{D}\right)$, average rainfall and statistical coefficients of the Mann-Kendall and Sen test for the state of Paraná in the period 1980-2010.

\begin{tabular}{|c|c|c|c|c|c|c|c|c|c|}
\hline \multirow{3}{*}{ Locality } & \multicolumn{5}{|c|}{ Reference evapotranspiration } & \multicolumn{4}{|c|}{ Rainfall } \\
\hline & $\mathrm{ET}_{0 \mathrm{AC}}$ & $\mathrm{ET}_{0 \mathrm{D}}$ & $\mathrm{CV}$ & $\mathrm{K}-\mathrm{M}(\tau)$ & Sen's Slope & Average rainfall & $\mathrm{CV}$ & $\mathrm{K}-\mathrm{M}(\tau)$ & Sen's Slope \\
\hline & $\mathrm{mm} \mathrm{yr}^{-1}$ & $\mathrm{~mm} \mathrm{day}^{-1}$ & $\%$ & Trend & $\mathrm{mm} \mathrm{yr}^{-1}$ & $\mathrm{~mm} \mathrm{yr}^{-1}$ & $\%$ & Trend & $\mathrm{mm} \mathrm{yr}^{-1}$ \\
\hline Antonina & 659.3 & 1.8 & 12.8 & $0.3^{*}$ & 3.2 & 2315.8 & 23.9 & $-0.3^{*}$ & -39.5 \\
\hline Apucarana & 1062.3 & 2.9 & 6.6 & $0.3^{\text {ns }}$ & 3.3 & 1619.1 & 16.6 & $-0.2^{\mathrm{ns}}$ & -7.6 \\
\hline Bandeirantes & 1231.9 & 3.4 & 6.8 & $0.2^{\mathrm{ns}}$ & 3.3 & 1442.3 & 17.5 & $-0.2^{\mathrm{ns}}$ & -9.3 \\
\hline Bela Vista & 979.0 & 2.7 & 5.4 & $0.0^{\mathrm{ns}}$ & 0.7 & 1527.1 & 16.9 & $-0.4^{*}$ & -18.3 \\
\hline Cambará & 1139.7 & 3.1 & 6.0 & $0.0^{\mathrm{ns}}$ & -0.4 & 1407.7 & 15.8 & $-0.2^{\text {ns }}$ & -5.8 \\
\hline Cândido Abreu & 927.9 & 2.5 & 7.2 & $0.18^{\mathrm{ns}}$ & 1.5 & 1659.3 & 17.5 & $-0.2^{\mathrm{ns}}$ & -7.6 \\
\hline Cascavel & 1096.4 & 3.0 & 7.4 & $0.3^{*}$ & 4.1 & 1899.9 & 19.1 & $-0.4^{*}$ & -18.3 \\
\hline Cerro Azul & 783.2 & 2.1 & 7.7 & $0.0^{\mathrm{ns}}$ & 0.1 & 1475.2 & 18.5 & $0.3^{*}$ & 13.0 \\
\hline Cianorte & 1120.4 & 3.1 & 6.0 & $0.1^{\text {ns }}$ & 0.8 & 1627.1 & 17.5 & $-0.2^{\mathrm{ns}}$ & -8.6 \\
\hline Clevelândia & 937.87 & 2.6 & 6.6 & $0.1^{\mathrm{ns}}$ & 0.4 & 2060.0 & 21.5 & $0.1^{\mathrm{ns}}$ & 4.4 \\
\hline Fernandes Pinheiro & 703.43 & 1.9 & 7.2 & $0.1^{\text {ns }}$ & 1.0 & 1635.9 & 20.0 & $-0.1^{\mathrm{ns}}$ & -6.0 \\
\hline Francisco Beltrão & 905.9 & 2.5 & 6.1 & $-0.2^{\mathrm{ns}}$ & -1.6 & 2067.8 & 22.9 & $0.0^{\mathrm{ns}}$ & -3.9 \\
\hline Guarapuava & 845.2 & 2.3 & 7.0 & $0.2^{\mathrm{ns}}$ & 1.8 & 1949.4 & 18.1 & $-0.2^{\mathrm{ns}}$ & -10.3 \\
\hline Guaraqueçaba & 578.6 & 1.6 & 7.9 & $-0.1^{\mathrm{ns}}$ & -1.0 & 2452.7 & 16.1 & $0.1^{\mathrm{ns}}$ & 7.7 \\
\hline Ibiporã & 1164.1 & 3.2 & 7.1 & $-0.1^{\mathrm{ns}}$ & -1.5 & 1515.3 & 18.6 & $-0.1^{\mathrm{ns}}$ & -8.0 \\
\hline Joaquim Távora & 1057.8 & 2.9 & 5.6 & $0.0^{\text {ns }}$ & 0.4 & 1432.8 & 15.0 & $-0.1^{\mathrm{ns}}$ & -2.2 \\
\hline Lapa & 715.9 & 2.0 & 6.4 & $-0.1^{\mathrm{ns}}$ & -1.1 & 1548.8 & 18.6 & $0.1^{\mathrm{ns}}$ & 6.9 \\
\hline Laranjeiras do Sul & 913.9 & 2.5 & 7.3 & $0.2^{\text {ns }}$ & 2.5 & 2055.5 & 17.3 & $-0.1^{\mathrm{ns}}$ & -8.9 \\
\hline Londrina & 1102.8 & 3.0 & 6.6 & $0.0^{\mathrm{ns}}$ & 0.9 & 1619.6 & 18.1 & $-0.1^{\mathrm{ns}}$ & -3.6 \\
\hline Mauá da Serra & 967.2 & 2.7 & 10.5 & $0.4^{*}$ & 7.0 & 1642.4 & 19.9 & $-0.4^{*}$ & -17.9 \\
\hline Morretes & 597.0 & 1.6 & 7.6 & $-0.2^{\mathrm{ns}}$ & -1.7 & 2018.2 & 15.5 & $0.1^{\text {ns }}$ & 7.4 \\
\hline Nova Cantu & 1069.1 & 2.9 & 6.7 & $-0.1^{\mathrm{ns}}$ & -1.3 & 1988.6 & 14.3 & $-0.1^{\mathrm{ns}}$ & -8.9 \\
\hline Palmas & 768.54 & 2.1 & 6.3 & $0.1^{\mathrm{ns}}$ & 0.6 & 2110.0 & 20.4 & $0.0^{\mathrm{ns}}$ & 0.9 \\
\hline Palotina & 1041.7 & 2.9 & 6.0 & $0.1^{\text {ns }}$ & 0.7 & 1662.2 & 21.2 & $-0.0^{\mathrm{ns}}$ & -3.2 \\
\hline Paranavaí & 1187.8 & 3.3 & 6.9 & $-0.2^{\mathrm{ns}}$ & -2.0 & 1487.3 & 16.8 & $0.0^{\mathrm{ns}}$ & -1.2 \\
\hline Pato Branco & 925.64 & 2.5 & 5.9 & $0.1^{\mathrm{ns}}$ & 0.8 & 2072.4 & 23.4 & $-0.1^{\mathrm{ns}}$ & -5.2 \\
\hline Pinhais & 667.7 & 1.8 & 11.7 & $0.3^{*}$ & 2.5 & 1503.0 & 17.2 & $0.0^{\text {ns }}$ & 3.6 \\
\hline Planalto & 1066.9 & 2.9 & 6.1 & $0.0^{\mathrm{ns}}$ & 0.7 & 1968.0 & 20.4 & $-0.1^{\mathrm{ns}}$ & -5.1 \\
\hline Ponta Grossa & 839.4 & 2.3 & 6.4 & $-0.2^{\mathrm{ns}}$ & -2.0 & 1624.5 & 20.7 & $0.0^{\text {ns }}$ & 0.3 \\
\hline Quedas do Iguaçu & 966.0 & 2.6 & 7.0 & $0.2^{\text {ns }}$ & 2.8 & 1994.1 & 18.6 & $-0.2^{\mathrm{ns}}$ & -11.6 \\
\hline São Miguel Iguaçu & 1031.4 & 2.8 & 5.8 & $0.2^{\mathrm{ns}}$ & 2.3 & 1820.5 & 16.9 & $-0.2^{\mathrm{ns}}$ & -7.6 \\
\hline Telêmaco Borba & 814.6 & 2.2 & 5.7 & $0.1^{\text {ns }}$ & 1.3 & 1622.8 & 14.9 & $-0.1^{\mathrm{ns}}$ & -6.4 \\
\hline Umuarama & 1180.5 & 3.2 & 6.6 & $-0.1^{\mathrm{ns}}$ & -1.4 & 1630.9 & 15.6 & $0.0^{\mathrm{ns}}$ & -0.5 \\
\hline
\end{tabular}

$\mathrm{ET}_{\mathrm{OAC}}$ - Evapotranspiration accumulated reference; $\mathrm{ET}_{\mathrm{OD}}$ - Evapotranspiration daily reference; CV - Coefficient of Variation; M-K - Mann-Kendall's test; Sen's Slope Sen's test. 


\subsection{Regionalization of the precipitation in Paraná}

The spatial variability of the precipitation in the State of Paraná from 1980 to 2010 ranged from $1407.7 \mathrm{~mm} \mathrm{yr}^{-1}$ in Cambará (northeast) to $2452.6 \mathrm{~mm} \mathrm{yr}^{-1}$ in Guaraqueçaba (north coast) (Figure 2D).

The highest precipitation occurred, in general, in the coastal and south-central regions of the state, with precipitation amounts above $2000 \mathrm{~mm} \mathrm{yr}^{-1}$. According to the Koppen classification, these regions have climate type $\mathrm{Cfb}$, which is characterized by the occurrence of abundant and well-distributed rainfall throughout the year. These characteristics may be related to the high altitudes of these regions (Figure 1), which slow air masses and frontal systems that promote rains from the coast (Nascimento Jr. and Sant'Anna Neto, 2015).

The regions with the lowest precipitations were the northwest and northeast, with precipitation amounts lower than $1500 \mathrm{~mm} \mathrm{yr}^{-1}$; however, Paraná has a low risk of soil water deficit, although this possibility must be assumed for some annual crops, mainly for those with socio-economic importance in these regions. The central region presented a significant and differentiated precipitation variability compared with the northwest, north, east and northeast regions of the state, with depths of about $1800 \mathrm{~mm} \mathrm{yr}^{-1}$.

The Paraná municipalities had high precipitation variability within the year, with amounts ranging from 800 to $3400 \mathrm{~mm} \mathrm{yr}^{-1}$ (Figure 4).

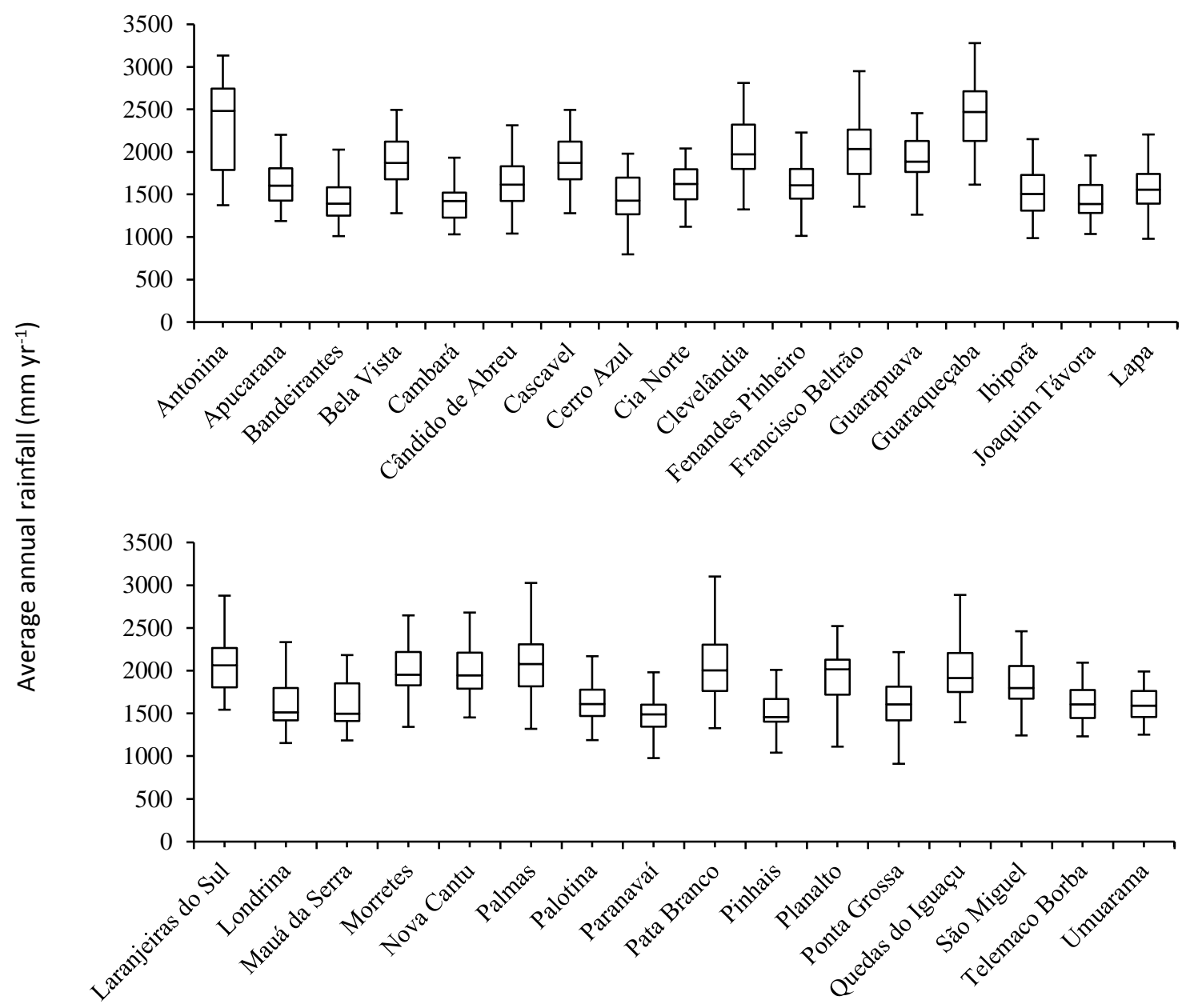

Figure 4. Bloxplot of the variability of annual accumulated rainfall, in the period 1980-2010, for the 33 studied municipal districts.

According to Sousa and Nery (2002) the phenomenon El Niño Southern Oscillation (ENSO), which presents anomalies of atmospheric pressure and temperature in the surface of the Equatorial Pacific Ocean, classified as El Niño (positive phase) and La Niña (negative 
phase), is one of the main large-scale factors that contribute to changes in atmospheric circulation, which are responsible for the precipitation variability within the year. Effects related to maritime (Atlantic Ocean), continentality (central and western state), relief (southern Geral Sierra and eastern Sea Sierra) and latitude (Tropic of Capricorn in the north) affect the precipitation to a lesser extent (regional level). Thus, to understand how these factors affect the precipitation dynamics of the state is important to identify their effect on activities that are dependent on them.

\subsection{Precipitation trend analysis in Paraná}

The average values of annual precipitation of each municipality and the statistical results of the Mann-Kendall and Sen tests for temporal trend analysis of this variable (Table 2), similarly to the results for the evapotranspiration, presented significant $(\mathrm{p}<0.05)$ trends in five (Bela Vista do Paraíso, Cerro Azul, Antonina, Cascavel and Mauá da Serra) of the 33 locations studied. However, different from the evapotranspiration, the precipitation trend was downward in these locations, except in Cerro Azul, which presented an upward trend.

The results showed temporal trends (significant at 5\%); however, $76 \%$ of the locations studied (25 municipalities) showed downward precipitation trends. Among the locations with upward trends, Cerro Azul, located in the east of the state, was the only one that had a significant $(\mathrm{p}<0.05)$ upward trend.

The variation rates from the Sen test showed decreasing rainfall of up to $39.5 \mathrm{~mm} \mathrm{yr}^{-1}$ (Antonina) and increasing rainfall of up to $13.0 \mathrm{~mm}$ (Cerro Azul). The municipalities Palmas, Ponta Grossa and Umuarama had the lowest increasing/decreasing rates of annual precipitation, with amounts lower than $1 \mathrm{~mm}$.

The results found in this study differ from those found by Minuzzi and Caramori (2011), who verified a trend of precipitation increase in the state of Paraná when they analyzed data from 21 hydrological stations. However, more recent research by Silva et al. (2015) corroborate the results identified in this study, since these authors verified trends of reduction in the annual rainfall in Paraná, mainly in the central and northern regions of the Paraná state, with increasing rainfall behavior only in the coast and southwest of the state.

Finally, we verify that the variables evapotranspiration and precipitation did not show statistically significant trends $(\mathrm{p}<0.05)$ in most of the stations analyzed in the state of Paraná. For municipalities where significant trends have been identified, these are located in distinct mesoregions of the territory of Paraná, and there is no evidence of specific regional behavior. However, when the analysis is restricted only to these municipalities, it can be observed that the behavior for the two variables is antagonistic, as can be observed in Figure 5, where the municipalities of Mauá da Serra and Antonina show increases in the annual values of evapotranspiration and decreases for accumulated precipitation. As reported by Collischonn and Tucci (2014) in a study that involved monthly relations between these two variables, this behavior is not uncommon, considering that a higher frequency of precipitation events tends to increase the relative humidity of the air, which in turn, would promote a reduction in the evapotranspirometric demand of the atmosphere.

Thus, despite the fact that significant trends were found in only $15 \%$ of the municipalities, the results indicated changes in the evapotranspiration and precipitation patterns, which can cause direct impacts on the agriculture of Paraná to a greater or lesser extent, contributing to changes in agricultural zoning. 


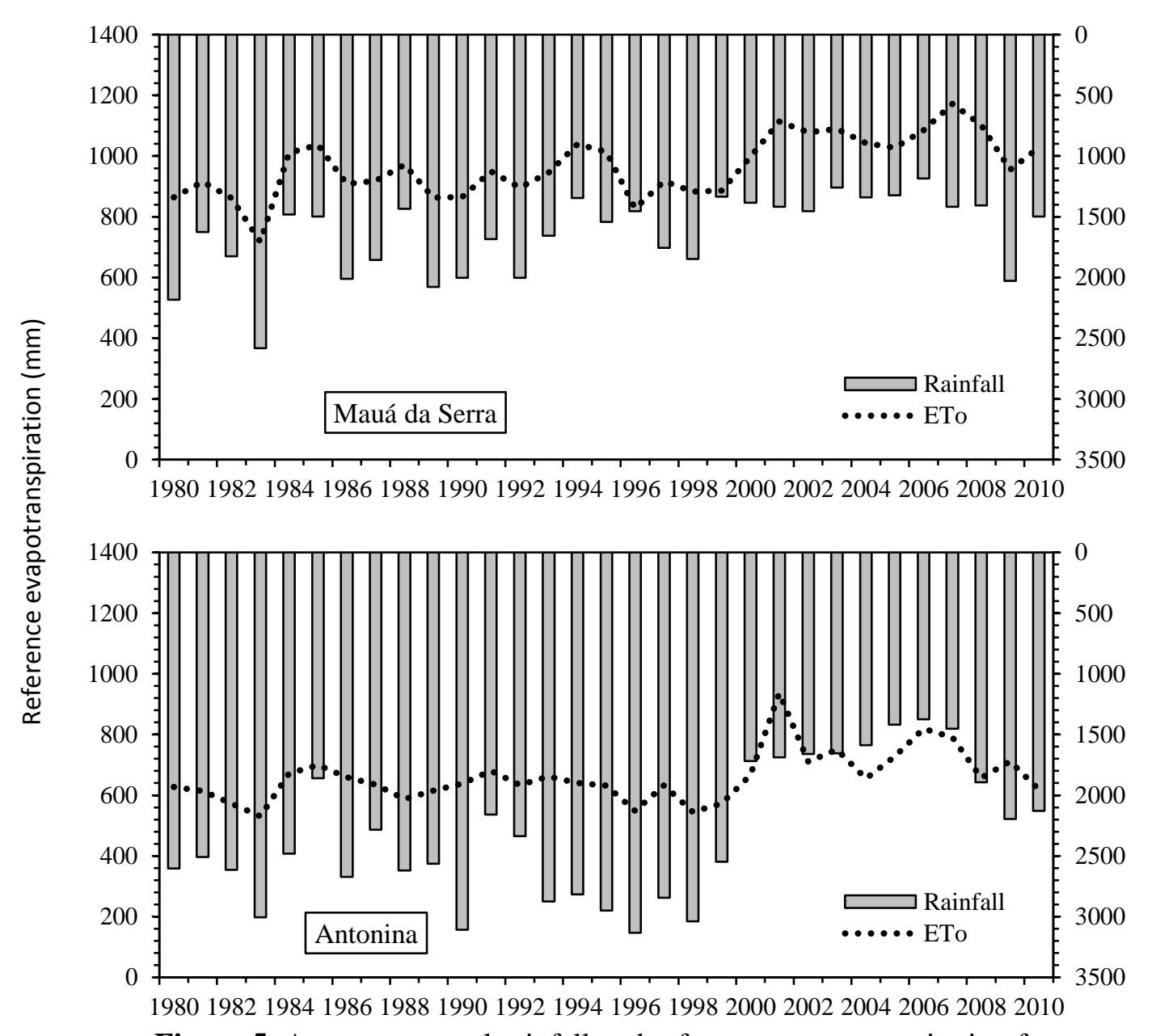

Figure 5. Averages annual rainfall and reference evapotranspiration for localities of Mauá da Serra and Antonina in the period 1980-2010.

\section{CONCLUSIONS}

The analysis of the evapotranspiration (ET) demand in the State of Paraná indicated that the $\mathrm{ET}_{0}$ increases from the coast to the interior of the state, with the highest values in the northeast and northwest regions, reaching $1200 \mathrm{~mm} \mathrm{yr}^{-1}$. The temporal results of the ET showed a significant upward trend in 4 of the 33 locations studied, with increases ranging from 2.5 to $7.0 \mathrm{~mm} \mathrm{yr}^{-1}$.

Precipitation presented the highest amounts in the coastal and south-central regions and the lowest amounts in the northeast and northwest regions. The precipitation trend analysis indicated a significant downward trend in the precipitation volume of five locations.

The evapotranspiration and precipitation showed, in general, no statistically significant trends in most of the stations analyzed; however, the upward trends for ET and downward trends for precipitation indicate local changes in the State of Paraná.

\section{ACKNOWLEDGEMENTS}

We would like to thank the funding agency Coordenação de Aperfeiçoamento de Pessoal de Nivel Superior (CAPES) for the post-doctoral scholarship of the first author and also the financial support through funding PNPD/CAPES (Agreement UEG/CAPES N. 817164/2015PROAP). The authors also thank IAPAR and University of São Paulo for the necessary support. 


\section{REFERENCES}

ABRAMOWITZ, M.; STEGUN, I. A. Handbook of Mathematical Functions with Formulas. Graphs. and Mathematical Tables. 10. ed. New York: Wiley, 1972. 1046 p.

ALLEN, R. G.; PEREIRA, L. S.; RAES, D.; SMITH, M. Crop evapotranspiration: guidelines for computing crop water requirements. Rome: FAO, 1998. 297p. (Irrigation and drainage paper, 56).

COLLISCHONN, B.; TUCCI, C. E. M. Relações regionais entre precipitação e evapotranspiração mensais. Revista Brasileira de Recursos Hídricos, v. 19, p. 205-214, 2014.

COMPANHIA NACIONAL DE ABASTECIMENTO - CONAB. Séries históricas de área plantada, produtividade e produção, relativas às safras 1976/77 a 2015/16 de grãos. 2001 a 2016 de café. 2005/06 a 2016/17 de cana de açúcar. 2016. Available in: http://www.conab.gov.br/conteudos.php?a=1252\&t=. Access in: September 2016.

DIGGLE, P. J.; RIBEIRO JÚNIOR, P. J. Model-based geostatistics. Londres: Springer, 2007. 230p.

FAN, Z.; THOMAS, A. Spatiotemporal variability of reference evapotranspiration and its contributing climatic factors in Yunman Province. SW China. 1961-2004. Climate Change, v. 116, n. 2, p. 309-325, 2013. http://dx.doi:10.1007/s10584-012-0479-4

HESS, T.; DACCACHE, A.; DANESHKHAH, A.; KNOX, J. Scale impacts on spatial variability in reference evapotranspiration. Hydrological Science Journal, v. 61, n. 3, p. 601-609, 2016. http://dx.doi.org/10.1080/02626667.2015.1083105.

JERSZURKI, D.; SOUZA, J. L. M.; EVANGELISTA, A. W. P. Probabilidade e variação temporal da evapotranspiração de referência na região de Telêmaco Borba - PR. Revista Brasileira de Biometria, v. 33, n. 2, p. 118-129, 2015.

JHAJHARIA, D.; DINPASHOH, Y.; KAHYA, E.; SINGH, V. P.; FAKHERI-FARD, A. Trends in reference evapotranspiration in the humid region of northeast India. Hydrological Processes, v. 26, n. 3, p. 421-435, 2012. http://dx.doi:10.1002/hyp.8140

KENDALL, M.; GIBBONS, J. D. Rank Correlation Methods. 5. ed. New York: A Charles Griffin Book, 1990. 272p.

KHALIL, A. A.; ESSA, Y. H.; ABDEL-WAHAB, M. M. Evapotranspiration mapping over Egypt using MODIS/Terra satellite data. International Journal of Advanced Research, v. 15, n. 12, p. 512-522, 2015.

LI, Z. L.; TANG, R.; WAN, Z.; BY, Y.; ZHOU, C.; TANG, B.; YAN, G.; ZHANG, X. A review of current methodologies for regional evapotranspiration estimation from remotely sensed data. Sensor, v. 9, p. 3801-3853, 2009. http://dx.doi.org/10.3390/s90503801.

MAUSER, W.; SCHADLICH, S. Modelling the spatial distribution of evapotranspiration on different scales using remote sensing data. Journal of Hydrology, v. 212-213, p. 250267, 1998. http://dx.doi.org/10.1016/S0022-1694(98)00228-5. 
McVICAR, T. R. et al. Global review and synthesis of trends in observed terrestrial near-surface wind speeds: Implications for evaporation. Journal of Hydrology, v. 416-417, p. 182205, 2012. http://dx.doi.org/10.1016/j.jhydrol.2011.10.024

MINUZZI, R. B.; CARAMORI, P. H.; Variabilidade climática sazonal e anual da chuva e veranicos no estado do Paraná. Revista Ceres, v. 58, n. 5, p. 593-602. 2011, http://dx.doi.org/10.1590/S0034-737X2011000500009

NASCIMENTO JÚNIOR, L.; SANT'ANNA NETO, J. L. Contribuição aos estudos da precipitação no estado do Paraná: a oscilação decadal do pacífico - ODP. Revista Raega, v. 35, p. 314-343, 2015. http://dx.doi.org/10.5380/raega.v35i0.42048

PEDRON, I. T.; KLOSOWSKI, E. S. Distribuição de frequência de chuvas diárias no Estado do Paraná. Scientia Agraria Paranaensis, v. 7, n. 1-2, p. 55-63, 2008. http://dx.doi.org/10.1818/sap.v0i0.2052

R CORE TEAM. R: A language and environment for statistical computing. R Foundation for Statistical Computing. Vienna, 2016. Available in: https://www.R-project.org/. Access in: September 2016.

SEN, P. K. Estimates of the regression coefficient based on Kendall's TAU. Journal of the $\begin{array}{llllll}\text { American Statistical Association, v. } & \text { 63, } & \text { p. 1379-1389, }\end{array}$ http://dx.doi.org/10.2307/2285891

SENTELHAS, P. C.; GILLESPIE, T. J.; SANTOS, E. A. Evaluation of FAO Penman-Monteith and alternative methods for estimating reference evapotranspiration with missing data in Southern Ontario. Canada. Agricultural Water Management, v. 97, n. 5, p. 635-644, 2010. http://dx.doi.org/10.1016/j.agwat.2009.12.001

SILVA, M. E. S.; GUETTER, A. K. Mudanças climáticas regionais observadas no estado do Paraná. Revista Terra Livre, v. 1, n. 20, p. 111-126, 2003.

SILVA, W. L.; DERECZYNSKY, C.; CHANG, M.; FREITAS, M.; MACHADO, B. J.; TRISTÃO, L.; RUGGERI, J. Tendências observadas em indicadores de extremos climáticos de temperatura e precipitação no estado do Paraná. Revista Brasileira de Meteorologia, v. 30, n. 2, p. 181-194, 2015. http://dx.doi.org/10.1590/0102778620130622

SOUZA, J. L. M.; JERSZURKI, D.; GOMES, S. Precipitação e evapotranspiração de referência prováveis na região de Ponta Grossa - PR. Irriga, v. 19, n. 2, p. 279-291, 2014. http://dx.doi.org/10.15809/irriga.2014v19n2p279.

SOUSA, P.; NERY, J. T. Análise da variabilidade anual e interanual da precipitação pluviométrica da região de Manuel Ribas. Estado do Paraná. Acta Scientiarum, v. 24, n. 6, p. 1707-1713, 2002. http://dx.doi.org/10.4025/actascitechnol.v24i0.2513

TABARI, H.; TALAEE, P. H. Recent trends of mean maximum and minimum air temperatures in the western half of Iran. Meteorology and Atmospheric Physics, v. 111, n. 3, p. 121131, 2011a. http://dx.doi:10.1007/s00703-011-0125-0

TABARI, H.; AEINI, A.; TALAEE, P. H.; SOME'E, B. S. Spatial distribution and temporal variation of reference evapotranspiration in arid and semi-arid regions of Iran. Hydrological Processes, v. 26, n. 4, p. 500-512, 2011b. http://dx.doi:10.1002/hyp.8146 
THOMAS, A. Spatial and temporal characteristics of potential evapotranspiration trends over China. International Journal of Climatology, v. 20, p. 381-396, 2000. http://dx.doi:10.1002/(SICI)1097-0088(20000330)20:4<381::AID-JOC477>3.0.CO;2-K

XAVIER, A. C.; KING, C. W.; SCANLON, B. R. Daily gridded meteorological variables in Brazil (1980-2013). International Journal of Climatology, v. 36, n. 6, p. 2644-2659, 2015. http://dx.doi:10.1002/joc.4518

XU, C.; GONG, L.; JIANG, T.; CHEN, D.; SINGH, V. P. Analysis of spatial distribution and temporal trend of reference evapotranspiration and pan evaporation in Changjiang (Yangtze River) catchment. Journal of Hydrology, v. 327, p. 81-93, 2006. http://dx.doi.org/10.1016/j.jhydrol.2005.11.029 